ORIGINAL ARTICLE

\title{
Leptin promoter gene polymorphism on -2549 position decreases plasma leptin and increases appetite in normal weight volunteers
}

\author{
Sandra B. Coelho ${ }^{\mathrm{a}, *}$, Patrícia G. Cardoso a, Josefina Bressan ${ }^{\mathrm{b}}$, Neuza M.B. Costa ${ }^{\mathrm{c}}$, \\ and Rita C.G. Alfenas ${ }^{b}$
}

a Universidade Federal de Lavras, Lavras, Minas Gerais, Brazil

${ }^{\mathrm{b}}$ Universidade Federal de Viçosa, Viçosa, Minas Gerais, Brazil

'Departamento de Nutrição, Universidade Federal do Espírito Santo, Alegre, ES, Brazil

Received August 29, 2011; accepted November 29, 2011

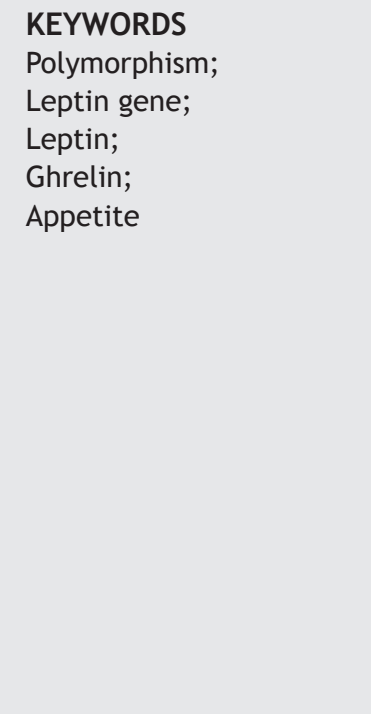

\section{KEYWORDS}

ymorphism;

Leptin;

Ghrelin

Appetite

\begin{abstract}
Investigate whether polymorphism in the promoter region encoding leptin and leptin receptor gene, in normal weight individuals, affects hormonal and appetite responses to peanuts.

Materials and methods: Appetite, anthropometric indices, body composition, physical activity, dietary intake and leptin, ghrelin and insulin levels were monitored. Polymorphism analyses were also carried out.

Results: None of the treatments led to statistical differences in the analyzed hormones. No polymorphism was found for leptin receptor gene, while for leptin gene, 50\% of the volunteers presented one polymorphic allele and $13 \%$ presented both polymorphic alleles. These last ones presented lower body fat mass, leptin and ghrelin plasma concentrations, and fullness rates. They also presented higher hunger, desire to eat, and desire to eat sweet and salty foods.

Conclusions: Peanut did not affect appetite and presented no different hormonal responses, compared to other foods studied. Polymorphic allele carriers in both alleles presented higher probability to develop obesity. However, the magnitude of this probability could not be measured.

(c) 2011 Asociación Española de Dietistas-Nutricionistas. Published by Elsevier España, S.L. All rights reserved.
\end{abstract}

\footnotetext{
${ }^{*}$ Corresponding author.

E-mail: sandracoelho@dca.ufla.br (S. Bragança Coelho). 


\section{PALABRAS CLAVE \\ Polimorfismo; \\ Gen de la leptina; \\ Leptina; \\ Grelina; \\ Falta de apetito}

El polimorfismo del promotor del gen de la leptina en la posición -2549 disminuye la leptina plasmática y aumenta el apetito de los voluntarios con peso normal

\section{Resumen}

Objetivo: Identificar polimorfismos en la región promotora del gen del receptor de la leptina en los individuos con peso normal e investigar si este polimorfismo afecta a las respuestas hormonales y el apetito tras la ingesta de cacahuetes o una mezcla de ingredientes con un aporte de macronutrientes semejante.

Material y método: Se controló el apetito, los índices antropométricos, la composición corporal, la actividad física, la ingesta dietética y las concentraciones de leptina, grelina e insulina de todos los sujetos. Además, se llevaron a cabo los análisis de polimorfismo.

Resultados: Ninguno de los tratamientos dio lugar a una diferencia estadísticamente significativa en las hormonas analizadas. No se encontró polimorfismo del gen del receptor de leptina, pero para el gen de la leptina, el 50\% de los voluntarios tenían un alelo polimórfico y el $13 \%$, dos. Estos presentaron menores índices de masa grasa corporal, concentraciones plasmáticas de leptina y grelina y tasas de plenitud gástrica. Asimismo, tenían más hambre, deseo de comer y deseo de comer algo dulce y salado.

Conclusiones: Ingerir cacahuetes no afecta al apetito y no produce respuestas hormonales diferentes que con otros alimentos estudiados. Los portadores de alelos polimórficos en los dos alelos tuvieron mayor probabilidad de sufrir obesidad, aunque no ha sido posible evaluar su magnitud.

๑ 2011 Asociación Española de Dietistas-Nutricionistas. Publicado por Elsevier España, S.L. Todos los derechos reservados.

\section{Introduction}

Nutrigenetics is the interaction between diet habits and the individual genetic profile ${ }^{1}$. Therefore, nutrigenetics aims to understand how the genetic makeup of an individual controls the response to diets, considering underlying genetic polymorphisms ${ }^{2}$.

Polymorphisms refer to the occurrence in the same population and at the same time of two or more distinct forms of a gene. These forms must occur in more than $1 \%$ of the individuals of a given population to be called polymorphism. Polymorphism is usually caused by changes in a single nucleotide in a DNA sequence of a gene (SNP) ${ }^{3}$.

Peanuts are rich in proteins, unsaturated fat, folic acid, magnesium fibers and antioxidants ${ }^{4}$. The regular consumption of peanuts improves lipid profiles ${ }^{5}$, thereby lowering cardiovascular disease risk. In spite of its high energy content, peanut consumption does not promote weight gain $^{6,7}$. The mechanisms responsible for this phenomenon have not been fully elucidated, but a strong satiety effect has been documented, possibly due to the high fiber and protein content of peanuts ${ }^{8,9}$.

Appetitive sensations are reportedly modulated by a variety of hormones ${ }^{10}$ that may affect food choice and energy intake. Circulating leptin concentrations are proportional to body fat content, similarly to insulin concentrations, but the latter are also more sensitive to recent energy and macronutrient consumption ${ }^{11,12}$. Insulin mediated glucose metabolism stimulates leptin synthesis and secretion ${ }^{13}$. The effective stimuli for ghrelin secretion have not been fully understood, but the energy status may be important. Fasting increases plasma ghrelin concentration while feeding leads to a decline ${ }^{11,14}$. However, it may be also modulated by insulin ${ }^{15,16}$. Thus, an elevation of postprandial insulin could be partly predicted to decreased hunger, by stimulating leptin secretion or reducing ghrelin secretion.

This study aimed to identify polymorphisms in the promoter region of the gene encoding leptin and leptin receptor in normal-weight individuals and to investigate whether these polymorphisms affect appetite responses to peanuts and also hormonal responses (leptin, insulin and ghrelin) in these individuals.

\section{Materials and methods}

\section{Subjects}

Forty healthy, lean (BMI <25), non-smoking men $(n=20)$ and women $(n=20)$, between 18 and 50 years of age completed the study. The participants were recruited at the Universidade Federal de Viçosa, Brazil. The following enrollment criteria were applied: stable weight, no medication use (except oral contraceptives), test foods rated as palatable, non restrained eaters, and adoption of a regular food pattern. The protocol received approval for human subject testing from the university committee on ethics, and all subjects signed a consent term agreeing to participate in the study.

\section{Experimental design}

The volunteers went to the laboratory for reporting once a week, for 4 weeks, at their customary midday mealtime. They were instructed to eat the same, customary breakfast 
each morning and to fast between this meal and their arrival at the laboratory. In 2 sessions, they consumed either peanut (PG) or a mix (MG). In addition, each participant completed 2 control sessions, in which the test load comprised a portion of the study lunch.

\section{Test Load}

The two treatments were PG - salted peanuts; MG - fiber cereal + crunchy cheese + potato chips. The average macronutrient composition was: $330 \mathrm{kcal} ; 16 \%$ carbohydrate; $17 \%$ protein; $67 \%$ fat.

The standard lunch comprised a sandwich, banana and chocolate. The control treatment was a representative portion of lunch. Its caloric content ( $330 \mathrm{kcal})$ was similar to that of the two study treatments, but differed in its macronutrient composition: $50 \%$ carbohydrate; $16 \%$ protein; $34 \%$ fat.

\section{Diet assessment}

In each session, the participants recorded types and amounts of foods consumed on the day of the test, and on an additional week and weekend day. Food records were evaluated by the DietPro ${ }^{\oplus}$, a Brazilian-specific nutrient database. The intake of energy, carbohydrate, lipid, protein, total saturated fatty acid, total polyunsaturated fatty acid, total monounsaturated fatty acid and cholesterol was estimated according to the food records.

\section{Anthropometric measurements}

Height, weight, lean body mass, and total body fat were assessed at baseline, while weight was also assessed at each session. The participants were weighed in light indoor clothing. Bioelectrical impedance was used to determine total body fat and the percentage of lean body mass and fat mass.

\section{Energy expenditure}

The participants received individualized midday meals providing $30 \%$ of their estimated daily energy need. The Institute of Medicine equations (EER) were used to estimate energy expenditure ${ }^{17}$.

\section{Physical activity assessment}

The participants maintained 24-hour physical activity logs during each session to determine the maintenance of their normal activities during the study. The data were analyzed using the Nutri Quest ${ }^{\oplus}$ software, version 2.1.

\section{Appetite ratings}

Subjective appetite ratings of hunger, fullness, and desire to eat were obtained on 13-point category scales at each study session. Scales had end anchors of "not at all" and "extremely". The participants completed the appetiterating questionnaire immediately before the consumption of test foods and also at 15, 30, 45, 60, 90, 120, 135, 150,
165, 180, 210, 240, 270 and 300 minutes after it, and hourly, for the remaining hours they were awake.

\section{Hormone assays}

Blood samples from times 0, 30, 120 and 300 minutes were collected and plasma ghrelin, leptin and insulin were determined by radioimmunoassay (RIA) in a random subsample of 30 individuals. The samples were analyzed on an Auto Logic Gamma Counter.

\section{Polymorphism assessment for LEP and LEP-R gene}

\section{Total DNA extraction}

Total DNA of 30 patients was extracted from blood cells using the GFX Genomic Blood DNA Purification Kit. Then, $900 \mu \mathrm{L}$ of RBC lysis solution was added to $300 \mu \mathrm{L}$ of blood. After homogenization, the mixture was incubated for 5 minutes at room temperature. Then, centrifugation was performed at $12000 \mathrm{rpm}$ for 20 seconds. The supernatant was discarded and the pellets containing white blood cells were resuspended by vortexing with $500 \mu \mathrm{L}$ of extraction solution. The mixture was incubated again for 5 minutes at room temperature and transferred to collection tubes with the GFX column for DNA purification and centrifuged at $8000 \mathrm{rpm}$ for 1 minute.

The collection tube supernatant was discarded and 500 $\mu \mathrm{L}$ of extraction solution were added in GFX column. After centrifugation at $8000 \mathrm{rpm}$ for 1 minute, the supernatant was discarded again. Then $500 \mu \mathrm{L}$ of washing solution were added to the GFX column. After centrifugation at 12000 rpm for 3 minutes, the supernatant was discarded again. The GFX column was transferred to a new collection tube and the DNA was eluted from the column using $100 \mu \mathrm{L}$ of Milli-Q water autoclaved at $70{ }^{\circ} \mathrm{C}$ after centrifugation at $8000 \mathrm{rpm}$ for 1 minute. The amount of DNA was estimated by electrophoresis in $0.8 \%$ agarose gel.

DNA fragment amplification

Amplification reactions were performed in a final volume of $50 \mu \mathrm{L}$ containing $1.0 \mu \mathrm{L}$ of DNA template, $1 \mu \mathrm{L}$ of each primer, $1 \mu \mathrm{L}$ of dNTP, $10 \mu \mathrm{L}$ Taq buffer and $0.25 \mu \mathrm{L}$ of Taq DNA polymerase. The primers used in amplification for the gene promoter region that encodes leptin hormone were LEP $F$ (5'-TTTCCTGTAATTTTCCCGTGAG-3 ') and LEP $R$ (5'-AAAGCAAAGACAGGCATAAAAA-3') and the primers used in the amplification of DNA fragment containing part of the coding region of the gene that encodes leptin receptor were LEP-R F (5'-CACATTGTACAATGGAAGCACAAAGTT-3') and LEP-R R (5'-TGTTAAAATCATAGCCATAAGACATCT-3').

The amplifications were performed in a thermocycler, with an initial step of 2 minutes at $94^{\circ} \mathrm{C}$, programmed for 30 cycles of 45 seconds at $94^{\circ} \mathrm{C}, 45$ seconds at $56^{\circ} \mathrm{C}$ and 1 minute and 30 seconds at $72^{\circ} \mathrm{C}$. Next, a step of 5 minutes at $72^{\circ} \mathrm{C}$ was carried out.

\section{Precipitation of amplified DNA fragments and cleavage with restriction enzymes}

The amplification reactions (two per sample) were transferred to $1.5 \mathrm{~mL}$ Eppendorf tube and received the addition of $1.5 \mu \mathrm{L}$ of $5 \mathrm{M} \mathrm{NaCl}$ and 2.5 volumes of ethanol. 
The mixture was incubated at $-20^{\circ} \mathrm{C}$ for 16 hours. It was then centrifuged at $12000 \mathrm{rpm}$ for 30 minutes and the supernatant was discarded. The pellet was washed with $70 \%$ ethanol and dried at room temperature. Then, the pellet was resuspended in $20 \mu \mathrm{L}$ of Milli-Q water.

Cleavage reactions were performed in a final volume of 25 $\mu \mathrm{L}$ containing $20 \mu \mathrm{L}$ of purified DNA fragment, $2.5 \mu \mathrm{L}$ of enzyme buffer and $1 \mu \mathrm{L}$ of enzyme. The digestion was conducted with Cfol enzyme for LEP fragment and Haelll enzyme for LEP-R fragment. The cleavage reaction was incubated at $37^{\circ} \mathrm{C}$ for $4 \mathrm{~h}$ and the products generated were separated in $2 \%$ agarose gel. After electrophoresis, the gel was viewed with UV light and photographed. The size marker DNA used was PhiX174 digested with Hinfl (Promega ${ }^{\circledR}$ ).

\section{Statistical analysis}

The data were checked for normality by the KolmogorovSmirnov test. Due to the non-normal distribution of the data, the analyses were conducted by non-parametric tests.

The treatment effects on rank procedure were tested by the ANOVA. Significant effects were further evaluated by the Tukey multiple comparisons procedure or Dunn's test, when group sizes differed. The Mann-Whitney test was used for between-group comparisons when necessary. The criterion level for statistical significance was $P<.05$, twotailed. All tests were performed with Sigma Stat 2.0 software system.

\section{Results}

\section{Anthropometric measurements}

All volunteers presented normal weight and there were no significant differences of weight or BMI among the four test sessions.

\section{Energy expenditure}

The EER median for PG was $2342 \mathrm{kcal} /$ day $(\mathrm{n}=20)$ and $M G=2228 \mathrm{kcal} /$ day $(\mathrm{n}=20)$.

\section{Physical activity assessment}

The estimated energy expenditure from 24-hour activity logs did not differ among the 4 sessions of the study.

\section{Hormone assays}

The MG group presented higher overall hormone concentrations. However, no treatment effects were observed on hormone concentrations (fig. 1).

\section{Polymorphism assessment for LEP and LEP-R gene}

The small number of samples in each treatment did not allow the performance of the statistical analysis of the data for the evaluation of polymorphisms in the leptin gene and leptin receptor for each treatment separately.
A

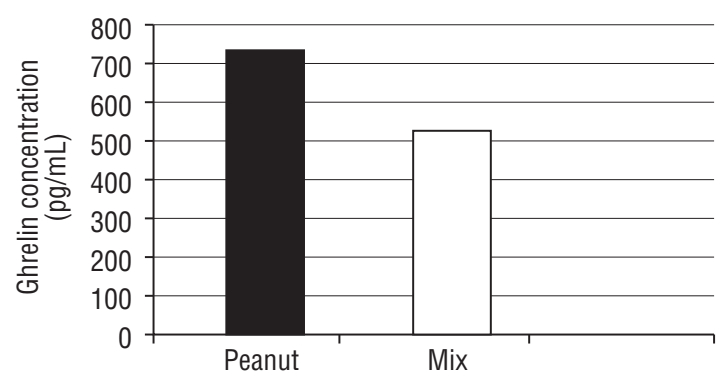

B
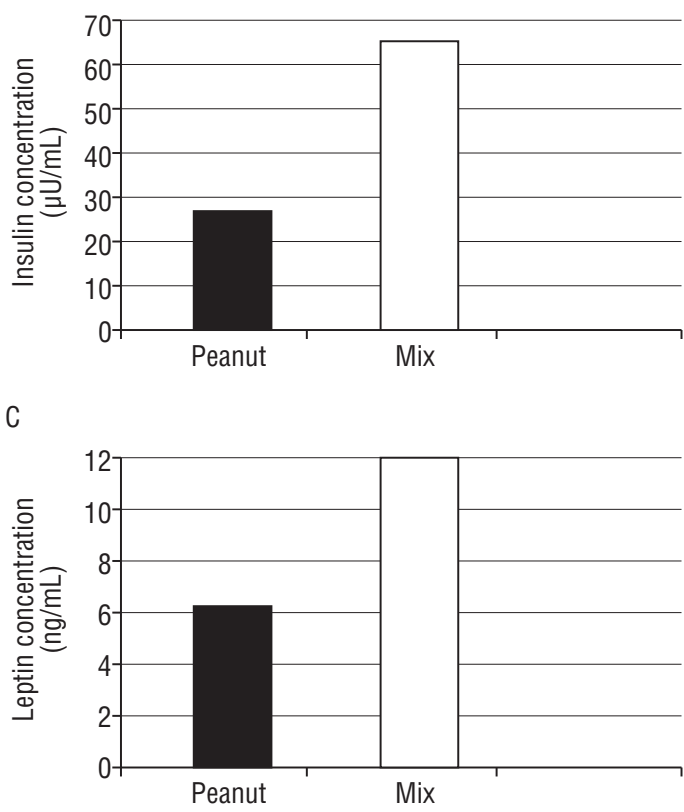

Figure 1 Comparison of the medians of hormones -ghrelin $(A)$, insulin (B) and leptin (C)- present in the four blood withdrawals from the volunteers from the 2 study treatments during the 4 study sessions. Medians with different letters are statistically different $(P<.05)$.

Since the treatments under study did not affect hormonal response differently and the results from group divisions were not likely to undergo statistical analysis, we decided to perform polymorphism analysis in individuals as a whole, only performing separation by polymorphisms.

For leptin gene at the position -2549 in total sample $(n=30), 37 \%$ presented no polymorphism, $50 \%$ presented one polymorphic allele $(\mathrm{AC})$ and $13 \%$ presented both polymorphic alleles (AA). Polymorphisms were not found for leptin receptor gene.

\section{Polymorphisms in the promoter region of leptin gene} versus interest parameters

There was no association between gene polymorphism and $\mathrm{BMI}$ at the position -2549 on leptin gene.

Genotype CC carriers, without the polymorphic allele A, presented higher $(\sim 20 \%)$ fat percentage than other CA and AA genotypes $(\sim 10 \%)$ and, consequently, lower fat-free mass percentage. Since CC genotype correlated with higher 
A

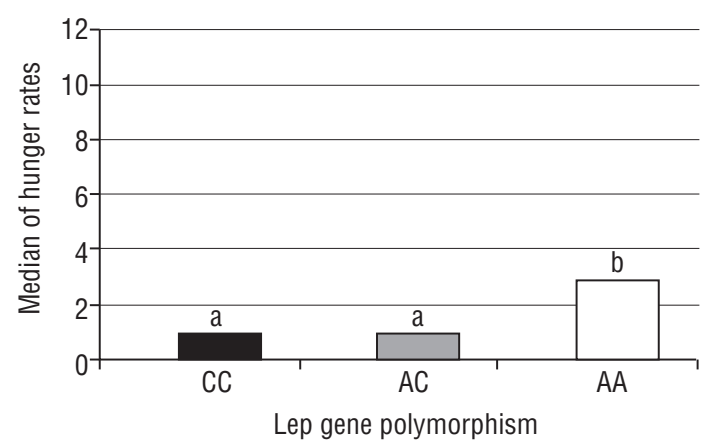

B

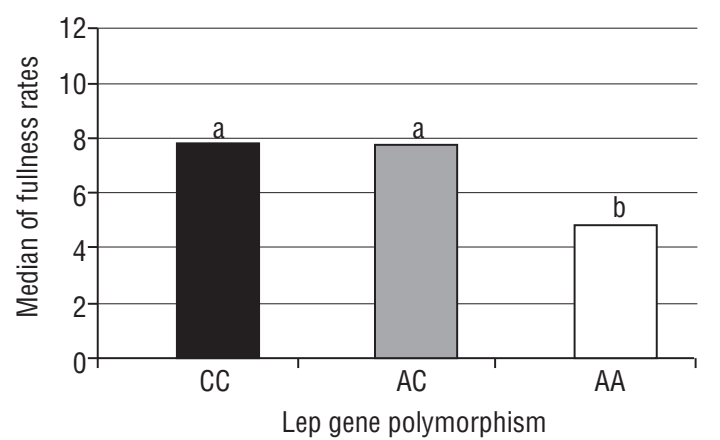

Figure 2 Median of hunger rates (A) and fullness rates (B) of the volunteers during the 4 study sessions and its relationship with leptin gene (LEP) at the position -2549 polymorphism ( $\mathrm{n}=30 ; 50 \%$ males and $50 \%$ females). $\mathrm{C}=$ normal allele, $\mathrm{A}=$ polymorphic allele. Medians with different letters are statistically significant.

plasma leptin levels in various studies ${ }^{18-21}$, individuals with this genotype were expected to have higher percentage of fat mass, since leptin is produced in this tissue.

Individuals carrying the polymorphic allele (A) at the position -2549 in one or both alleles presented significantly lower plasma leptin $(\mathrm{AC}=5 \mathrm{ng} / \mathrm{mL}$ and $\mathrm{AA}$ approximately $1,8 \mathrm{ng} / \mathrm{mL}$ ), compared to individuals without this allele (13 $\mathrm{ng} / \mathrm{mL}$ ). It is worth mentioning that the presence of polymorphism in both alleles usually occurred at low values of plasma leptin, but this difference was not statistically significant, possibly due to the small number of individuals belonging to this group.

Regarding plasma ghrelin values, these levels are lower (AA, $500 \mathrm{pg} / \mathrm{mL}$, and $\mathrm{AC}, 600 \mathrm{pg} / \mathrm{mL}$ ) in individuals with the polymorphic allele $A$, compared to individuals without polymorphism (CC, $700 \mathrm{pg} / \mathrm{mL}$ ).

There was no statistical difference in plasma insulin concentrations for polymorphisms at the position - 2549 on leptin gene, in spite of the trend in AA individuals for lower leptin values (AA, $34 \mu \mathrm{U} / \mathrm{mL}$; AC, $43 \mu \mathrm{U} / \mathrm{mL}$; CC, $44 \mu \mathrm{U} /$ $\mathrm{mL})$.

Figure $2 \mathrm{~A}$ shows that individuals with polymorphism in both alleles (AA) have higher hunger rates and, consequently, lower fullness rates (fig. 2B) than the other genotypes. These individuals (AA) presented greater desire to eat than the other genotypes (AC and CC) (fig. 3A). The desire to eat sweets and salty foods was higher in patients with the AA genotype (figs. 3B-D).

\section{Discussion}

The presence of polymorphism at the leptin gene promoter region has been associated with leptin level fluctuations. Mammés ${ }^{21}$ described several polymorphisms related to the leptin gene. The allele at the position - 2549 was associated with increased plasma leptin levels before diet restriction, and the association did not depend on BMI. The opposite effect was found by Le Stunff et $\mathrm{al}^{18}$, who observed that women with the AA genotype for the -2549 position exhibited lower mean plasma leptin compared to those with $\mathrm{AC}$ and $\mathrm{CC}$ genotypes. It should be observed that none of these polymorphisms mentioned above was associated with BMI.

In this study, we observed an association between the polymorphic allele and lower plasma leptin. However, higher levels of the hormone found in patients with CC alleles (non-polymorphic) are considered normal, because reference values for plasma leptin in normal weight women are: 2.0 to $17.0 \mathrm{ng} / \mathrm{mL}$; and in normal weight men are: 1.0 to $11.0 \mathrm{ng} / \mathrm{mL}$. This result is consistent with the fact that these CC individuals presented higher fat mass percentage since leptin is a hormone produced by fat cells. Therefore, individuals with higher fat stores were expected to produce higher amounts of leptin. The AA and AC individuals presented lower plasma leptin and, consequently, lower body fat percentages. The same finding has been reported in the literature ${ }^{18,20,21}$. Obese girls with the AA genotype also presented 20 to $25 \%$ lower plasma leptin levels, compared to other genotypes ${ }^{19}$.

The values of plasma ghrelin in individuals carrying polymorphic allele A were also lower than those for noncarriers of this allele. However, the magnitude of this decrease was considerably smaller $(28 \%)$ for ghrelin than for leptin (75\%). This means that these individuals carrying the polymorphic allele for leptin promoter at the position -2549 tended to present increased food intake and decreased satiety. It is not possible to say whether these ghrelin concentration values are at normal range or above it for this hormone, since there are no reference values available for ghrelin because it has been discovered recently. However, one can compare these values with other values of plasma levels of total ghrelin reported in the literature. A study conducted by Leidy et al $^{23}$ involving non-obese women found that control subjects had mean values of total $24 \mathrm{~h}$ ghrelin equal to $1616 \pm 122 \mathrm{pg} / \mathrm{mL}$ and $1511 \pm 173 \mathrm{pg} / \mathrm{mL}$ for $2 \mathrm{~h}$ before and after lunch. These values are very similar to the protocol of this study. Aydin et $\mathrm{al}^{24}$ found values well below those in their study, with fasting ghrelin in normal weight men and women of $126.4 \pm 38.5 \mathrm{pg} / \mathrm{mL}$. However, Williams et $\mathrm{al}^{25}$ revealed mean values of $24-\mathrm{h}$ ghrelin in obese individuals, ranging from $300 \mathrm{pg} / \mathrm{mL}$ at $10: 00$ to values close to $500 \mathrm{pg} / \mathrm{mL}$ at 18:00. The values found in this study varied from 500 to $800 \mathrm{pg} / \mathrm{mL}$ for the median of the measurements performed after fasting for $4 \mathrm{~h}$ and other three doses in the postprandial period, totaling $5 \mathrm{~h}$. Due to differences in the protocols of the studies, it is difficult to 
A

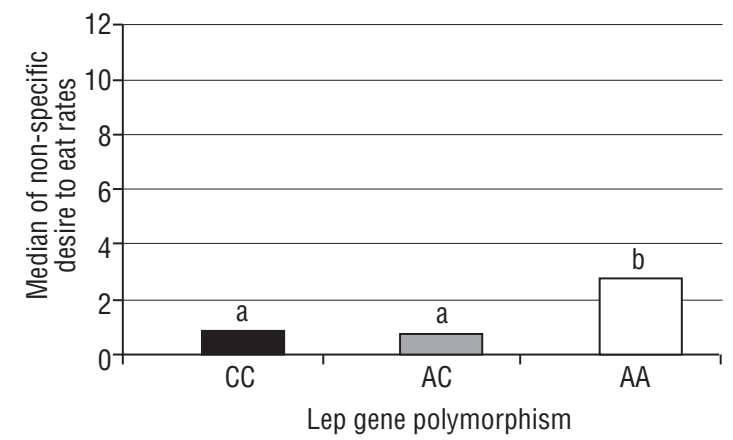

$B$

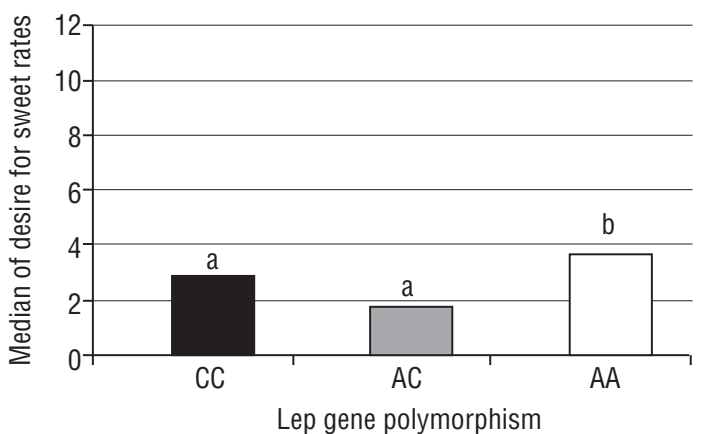

C

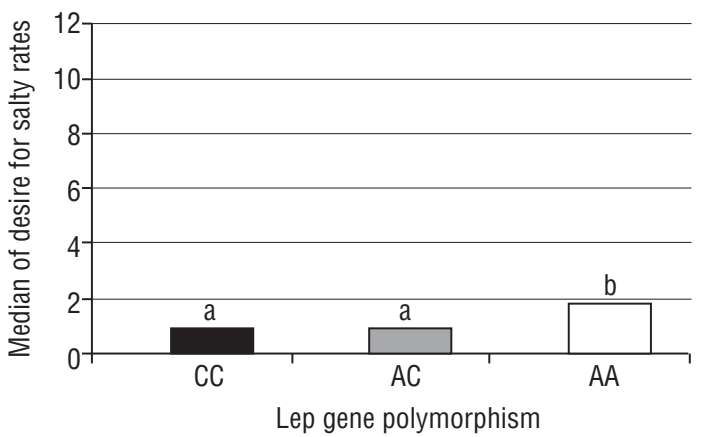

D

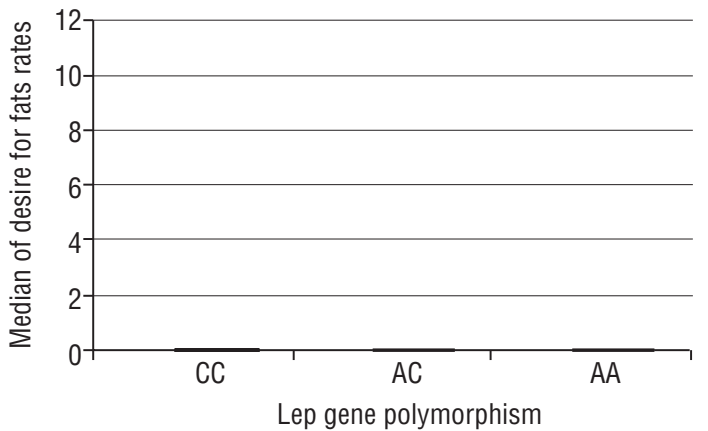

Figure 3 Non-specific desire to eat median rates (A); desire to eat sweet foods (B), salty foods (C) and fatty foods (D) during the 4 study sessions and their relationship with leptin gene (LEP) at the position -2549 polymorphisms ( $n=30 ; 50 \%$ males and $50 \%$ females). $\mathrm{C}=$ normal allele, $\mathrm{A}=$ polymorphic allele. Medians with different letters are statistically significant.

compare the plasma levels obtained in this study with others reported in literature.

The hormone insulin did not show any statistical difference for leptin gene at the position -2549 polymorphisms, although AA individuals tended to lower the levels of plasma insulin. The reference values for fasting insulin are 3-30 $\mu \mathrm{U} / \mathrm{mL}$. However, for this analysis, individuals need to fast for 8 to 14 hours and the volunteers of this study had fasted for only 4 hours before the first collection, which complicates a more accurate comparison. We have found only one study relating this polymorphism and plasma insulin concentration. In this study, Ren et $\mathrm{al}^{21}$ reported that in non-diabetic individuals who had relatives with diabetes, the presence of two polymorphic alleles (AA) resulted in lower fasting plasma insulin $(8.86 \pm 5.43 \mathrm{U} / \mathrm{mL})$. The same occurrence was observed in the presence of only one polymorphic allele (AC) $(9.96 \pm 4.40 \mu \mathrm{U} / \mathrm{mL})$ compared to individuals without the presence of polymorphism for this gene $(C C)(11.52 \pm 7.51 \mu \mathrm{U} / \mathrm{mL})$.

The trend of increased food intake and decreased satiety when addressing the relationship between polymorphisms and hormones is corroborated by the results for appetite. They revealed that individuals with polymorphic allele in the promoter region on leptin gene at the position -2549 in both alleles (AA) have higher rates of hunger than other genotypes. This may be partly explained by figure 3 , which shows that the plasma leptin of these volunteers was significantly lower, compared to that of individuals without polymorphism for this gene.
Leptin is able to inhibit orexigenic peptides (NPY and AGRP) while stimulating anorexigenic peptides (POMC and CART), thereby causing increased satiety and avoiding feeding ${ }^{26,27}$. Therefore, if individuals with genotype AA had lower rates of this hormone, they will probably present higher hunger rates and therefore lower fullness rates. These individuals (AA) had greater desire to eat than the other genotypes ( $\mathrm{AC}$ and $\mathrm{CC}$ ), and this desire to eat was higher for sweet and salty foods in AA genotype, which ultimately can lead to increased caloric intake, promoting weight gain.

The desire for sweets reached values higher than the non-specific desire to eat, possibly because the desire to consume carbohydrates, more specifically simple carbohydrates, reduces the synthesis of NPY with subsequent hunger relief. Once the volunteers were fasting and thus having hunger sensations, the craving for sweets would eliminate hunger faster ${ }^{28}$. Anderson et $\mathrm{al}^{29}$ reported that carbohydrates with high glycemic index (simple carbohydrates) have a greater satiety values and suppress hunger more than carbohydrates with low glycemic index (complex carbohydrates). This is still a controversial issue, since in a study of Alfenas et $\mathrm{a}^{30}$ where 39 healthy adults consumed foods with high or low glycemic index, no significant differences in appetite were observed (hunger, desire to eat and fullness).

The relationship between the results for appetite hormone concentrations and polymorphism in the promoter region of leptin gene at the position -2549 allows the establishment of a causative factor for obesity in individuals 
with polymorphism in both alleles. This is due to the fact that they have lower plasma leptin concentrations, higher hunger rates, lower fullness rates and greater desire to eat, mainly sweet foods. However, the magnitude of the increased probability to develop obesity could not be measured in this study. Therefore, further studies should be carried out for a more comprehensive investigation on this subject.

\section{Conflict of interests}

The authors declare no conflicts of interests.

\section{References}

1. Schuch JB, Voigt F, Maluf SW, Andrade FM. Nutrigenética: a interação entre hábitos alimentares e o perfil genético individual. Rev Bras Bioci. 2010;8:73-84.

2. Mutch DM, Wahli W, Williamson G. Nutrigenomics and nutrigenetics: the emerging faces of nutrition. FASEB J. 2005;19:160316.

3. Elliott RM, Johnson IT. Nutrigenomic approaches for obesity research. Obes Rev. 2007;8 Suppl 1:77-81.

4. Cruz ACRF. "Balanço energético em indivíduos saudáveis após consumo de grão, pasta, farinha ou óleo de amendoim" [Master dissertation]. Viçosa: Universidade Federal de Viçosa; 2006.

5. Alper CM, Mattes RD. Peanut consumption improves indices of cardiovascular disease risk in healthy adults. J Am Coll Nutr. 2003;22:133-41.

6. Hu FB, Stampfer MJ, Manson JE, Rimm EB, Colditz GA, Rosner $\mathrm{BA}$, et al. Frequent nut consumption and risk of coronary heart disease in women: prospective cohort study. $\mathrm{Br} \mathrm{J}$ Nutr. 1998;317:1341-5.

7. Iwamoto M, Sato M, Kono M, Hirooka Y, Sakai K, Takeshita A, et al. Walnuts lower serum cholesterol in Japanese men and women. J Nutr. 2000;130:171-6.

8. Burton-Freeman B. Dietary fiber and energy regulation. J Nutr. 2000;130:S272-5.

9. Kirkmeyer SV, Mattes RD. Effects of food attributes on hunger and food intake. Int J Obes. 2000;24:1167-75.

10. Degen L, Matzinger D, Drewe J, Beglinger C. The effect of cholecystokinin in controlling appetite and food intake in humans. Peptides. 2001;22:1265-9.

11. Cummings DE, Purnell JQ, Frayo RS, Schmidova K, Wisse BE, Weigle DS. A preprandial rise in plasma ghrelin levels suggests a role in meal initiation in humans. Diabetes. 2001;50:1714-9.

12. Tschop M, Wawarta R, Riepl RL, Friedrich S, Bidlingmairer M, Landgraf $R$, et al. Post-prandial decrease of circulating human ghrelin levels. J Endocrinol Invest. 2001;24:19-21.

13. Mueller WM, Gregoire FM, Stanhope KL, Mobbs CV, Mizuno TM, Warden $\mathrm{CH}$, et al. Evidence that glucose metabolism regulates leptin secretion from cultured rat adipocytes. Endocrinology. 1998;139:551-8.
14. Klok MD, Jakobsdottir S, Drent ML. The role of leptin and ghrelin in the regulation of food intake and body weight in humans: a review. Obes Rev. 2007;8:21-34.

15. Blom WA, Stafleu A, De Graaf C, Kok FJ, Schaafsma G, Hendriks HF. Ghrelin response to carbohydrate-enriched breakfast is related to insulin. Am J Clin Nutr. 2005;81:367-75.

16. Cummings DE, Frayo RS, Marmonier C, Aubert R, Chapelot D. Plasma ghrelin levels and hunger scores in humans initiating meals voluntarily without time- and food-related cues. Am J Physiol Endocrinol Metab. 2004;287:E297-304.

17. Dietary Guidelines for Americans and the new food pyramid, MyPyramid. Washington: Institute of Medicine (IOM); 2005.

18. Le Stunff $\mathrm{CL}$, Bihan $\mathrm{CL}$, Schork NJ, Bougnères PA. Common promoter variant of the leptin gene is associated with changes in the relationship between serum leptin and fat mass in obese girls. Diabetes. 2000;49:2196-200.

19. Yiannakouris N, Yannakoulia M, Melistas L, Chan JL, Klims-Zacas D, Mantzoros CS. The Q223R polymorphism of the leptin receptor gene is significantly associated with obesity and predicts a small percentage of body weight and body composition variability. J Clin Endocrinol Metab. 2001;86:4434-9.

20. Hoffstedt J, Eriksson P, Mottagui-Tabar S, Arner P. A polymorphism in the leptin promoter region $(-2548 \mathrm{G} / \mathrm{A})$ influences gene expression and adiposite tissue secretion of leptin. Horm Metab Res. 2002;34:355-9.

21. Ren W, Zhang SH, Wu J, Ni YX. Polymorphism of the leptin gene promoter in pedigrees of type 2 diabetes mellitus in Chongqing, China. Chin Med J. 2004;117:558-61.

22. Mammès $O$, Betoulle $D$, Aubert $R$, Giraud $V$, Tuzet $S$, Petiet $A$, et al. Novel polymorphisms in the 5' region of the LEP gene. Diabetes. 1998; 47:487-9.

23. Leidy HJ, Dougherty KA, Frye BR, Duke KM, Williams NY. Twenty-four-hour ghrelin is elevated after calorie restriction and exercise training in non-obese women. Obesity. 2007;15:44655.

24. Aydin S, Halifeoglu I, Ozercan IH, Erman F, Kilic N, Aydin S, et al. Comparison of leptin and ghrelin levels in plasma and saliva of young healthy subjects. Peptides. 2005;26:647-52.

25. Williams DL, Cummings DE. Regulation of ghrelin in physiologic and pathophysiologic states. J Nutr. 2005;135:1320-5.

26. Loos RJF, Rankinen T, Chagnon Y, Tremblay A, Perusse L, Bouchard C. Polymorphisms in the leptin and leptin receptor genes in relation to resting metabolic rate and respiratory quotient in the Québec Family Study. Int J Obes. 2006;30:183-90.

27. Klok MD, Jakobsdottir S, Drent ML. The role of leptin and ghrelin in the regulation of food intake and body weight in humans: a review. Obes Rev. 2002;8:21-34.

28. York DA, Bray GA. Animal models hyperphagia. En: Bouchard C, Bray GA, editors. Regulation of bodyweight: Biological and behavioral mechanisms. New York: John Wile \& Sons; 1996. p. $15-31$.

29. Anderson GH, Catherine NL, Woodend DM, Wolever TM. Inverse association between the effect of carbohydrates on blood glucose and subsequent short-term food intake in young men. Am J Clin Nutr. 2002;76:1023-30.

30. Alfenas RCG, Mattes RD. Influence of glycemic index/load on glycemic response, appetite, and food intake in healthy humans. Diabetes Care. 2005;28:2123-9. 